\title{
Rat subcutaneous tissue response to calcium silicate containing different arsenic concentrations
}

\author{
Paloma Gagliardi MINOTTI, Ronald ORDINOLA-ZAPATA, Raquel Zanin MIDENA, Marina Angélica MARCIANO, Bruno \\ Cavalini CAVENAGO, Clovis Monteiro BRAMANTE, Roberto Brandão GARCIA, Marco Antonio Hungaro DUARTE, \\ Ivaldo Gomes de MORAES
}

Department of Operative Dentistry, Endodontics and Dental Materials, Bauru School of Dentistry, University of São Paulo, Bauru, SP, Brazil.

Corresponding address: Paloma Gagliardi Minotti - Al. Octávio Pinheiro Brisolla, 9-75 - Bauru - SP - Brazil - $17012-901$ - Phone/Fax: +55 (14) 32358344 - e-mail: pallomma@usp.br

Submitted: September 10, 2013 - Modification: May 5, 2014 - Accepted: May 12, 2014

\section{ABSTRACT}

\begin{abstract}
O bjective: To evaluate the response of rat subcutaneous tissue in implanted polyethylene tubes that were filled with GMTA Angelus and Portland cements containing different arsenic concentrations. Material and Methods: Atomic absorption spectrophotometry was utilized to obtain the values of the arsenic concentration in the materials. Thirty-six rats were divided into 3 groups of 12 animals for each experimental period. Each animal received two implants of polyethylene tubes filled with different test cements and the lateral of the tubes was used as a control group. After 15, 30 and 60 days of implantation, the animals were killed and the specimens were prepared for descriptive and morphometric analysis considering: inflammatory cells, collagen fibers, fibroblasts, blood vessels and other components. The results were analyzed utilizing the Kuskal-Wallis test and the Dunn's Multiple test for comparison $(\mathrm{p}<0.05)$. Results: The materials showed, according to atomic absorption spectrophotometry, the following doses of arsenic: GMTA Angelus: $5.01 \mathrm{mg} / \mathrm{kg}$, WPC Irajazinho: $0.69 \mathrm{mg} / \mathrm{kg}$, GPC Minetti: $18.46 \mathrm{mg} / \mathrm{kg}$ and GPC Votoran: $10.76 \mathrm{mg} / \mathrm{kg}$. In a 60-day periods, all specimens displayed a neoformation of connective tissue with a structure of fibrocellular aspect (capsule). Control groups and MTA Angelus produced the lower amount of inflammatory reaction and GPC Minetti, the highest reaction. Conclusions: There was no direct relationship between the concentration of arsenic present in the composition of the materials and the intensity of the inflammatory reactions. Higher values, as $18.46 \mathrm{mg} / \mathrm{kg}$ of arsenic in the cement, produce characteristics of severe inflammation reaction at the 60-day period. The best results were found in MTA angelus.
\end{abstract}

Keywords: Arsenic. Endodontics. Dental materials. Subcutaneous tissue reaction. Portland cement.

\section{INTRODUCTION}

MTA is a mixture of hydrophilic powder consisting of tricalcium silicate, tricalcium oxide, silicate oxide and tricalcium aluminate ${ }^{2,21}$. Several in vivo and in vitro studies demonstrated the beneficial properties of MTA, such as biocompatibility ${ }^{20}$, promoting dental pulp and periradicular tissue regeneration ${ }^{1}$, excellent sealing ability ${ }^{23,24}$ and antimicrobial effects $^{8,22}$. Due to these properties, MTA has been recommended for several clinical applications.

Portland cement (PC) is the main component of $\mathrm{MTA}^{25}$ and has been studied since 1999 . Studies revealed similar chemical composition ${ }^{8,12,14}$, action mechanism ${ }^{10,11}$ and cytotoxicity ${ }^{17,19}$ for both materials. The only difference between them is the absence of bismuth oxide in PC, used as radiopacifier in MTA. It has been reported that Portland cement may contain some heavy metals in its composition, such as arsenic (As) $)^{3,4,7,15,18}$. The concentration of this metal varies according to the origin of the raw material used for the production of the Portland cement ${ }^{4}$.

As is a metalloid found in water, air and soil, in organic and inorganic forms and in different stages of oxidation. The trivalent and pentavalent stages are the most toxic ${ }^{11}$. The soluble As salts are easily absorbed orally and by inhalation, and 
the extent of absorption depends on the solubility of the compound. From the bloodstream, it is deposited into tissues, liver, kidneys and lungs ${ }^{11}$. The chronic exposure to inorganic As is associated to the deleterious effects to human health, such as hyperkeratosis, hyperpigmentation, cardiovascular diseases, central nervous system and peripheral vascular disorders, skin cancer and gangrene in the $\operatorname{limbs}^{16}$.

Due to its high toxicity, As may cause generalized tissue necrosis in the oral cavity when used for endodontic purposes ${ }^{9,26}$. A study by Duarte, et al. ${ }^{7}$ $(2005)$ evaluated the release of As in two gray PCs, one white PC, MTA Angelus and MTA ProRoot and found similar As levels between the materials, much below the limit established by the ISO 99171 specifications ${ }^{13}$, which state that a material may only be used in dental procedures when it does not contain more than $2 \mathrm{mg}$ of As per $\mathrm{kg}$ of material.

Regarding the concerns of the arsenic content in PC and MTA, a previous study ${ }^{3}$ observed the presence of As in several materials, including white and gray MTA Angelus, white and gray PC, MTA ProRoot, PCM, MTA-Obtura and an experimental MTA. Only MTA-Obtura, white MTA Angelus and white PC (Irajazinho, Cimento Rio Branco, Rio de Janeiro, RJ, Brazil) presented levels below the limits recommended by ISO $^{3}$.

Despite the variable presence of arsenic in these materials, no studies in the literature have compared the biocompatibility of Portland cement and MTA according to the arsenic concentrations. The aim of this study was to microscopically evaluate the tissue response in the subcutaneous tissue of rats to the implantation of polyethylene tubes containing MTA and Portland cements with different arsenic concentrations.

\section{MATERIAL AND METHODS}

\section{Animals and sample grouping}

The present study was approved and performed according to the guidelines of the Research and Ethics Committee of the Bauru School of Dentistry, University of São Paulo, Bauru, SP, Brazil (Process no. 024/2009). A total of 36 male animals (Rattus norvegicus albinus Wistar), approximately 2 to 3 months old and weighing around $200 \pm 50$ grams, were used for this experiment. The animals received appropriate granular food and water ad libitum.

The thirty-six rats were divided into 3 groups of 12 animals per experimental period of 15,30 and 60 days and each animal received two-polyethylene tubes containing different cements. The following materials were investigated: group 1: Gray MTA Angelus (MTA - Angelus, Angelus Indústria de Produtos Odontológicos S/A, Londrina, PR, Brazil); group 2: White Portland cement Irajazinho
(Irajazinho, Cimento Rio Branco, Rio de Janeiro, RJ, Brazil); group 3: Gray Portland cement Minetti (Minetti, Juan Minetti S/A, Cordoba, Cordoba, Argentine) and group 4: Gray Portland cement Votoran (Votoran, Votorantim Cimentos, Cubatão, SP, Brazil).

The cements were analyzed by the Hidrocepe - Quality Services Ltda. (Belo Horizonte-MG) laboratory, which quantified the levels of arsenic according to a previous related methodology ${ }^{3}$.

\section{Sample preparation}

The test materials were placed in sterile polyethylene tubes with $1.5 \mathrm{~mm}$ inner diameter and $10 \mathrm{~mm}$ length. GMTA Angelus (MTA - Angelus, Angelus Indústria de Produtos Odontológicos $S / A$, Londrina, PR, Brazil) was mixed according to the manufacturer's instructions. The powder/liquid ratio used for the Portland cements was $1 \mathrm{~g} / 0.35$ $\mathrm{mL}$ distilled water. The sterilized tubes were filled with the test materials with the aid of endodontic condensers.

\section{Surgical procedures}

The animals were anesthetized with 0.008 $\mathrm{mL} / 100 \mathrm{~g}$ of ketamine (Dopalen ${ }^{\circledR}$ - Vetbrands, CEVA, Paulínia, SP, Brazil) and $0.004 \mathrm{~mL} / 100 \mathrm{~g}$ of xylazine hydrochloride 2\% (Calmium ${ }^{\circledR}$ - Agener União, União Química, Embu-Guaçu, SP, Brazil). A dorsal shaving was performed, and the area was disinfected with an iodine solution (Riodene, Rioquímica Indústria Farmacêutica, São José do Rio Preto, SP, Brazil). The backs of the animals were incised over a length of $2 \mathrm{~cm}$, using a no. 15 blade (Embramac, Embramac - Empresa Brasileira de Materiais Cirúrgicos, Campinas, SP, Brazil) in a head-to-tail alignment orientation. A blunt dissecting instrument was used to create a $18 \mathrm{~mm}$ deep pocket in the subcutaneous tissue to receive the implants. Polyethylene tubes filled with the materials were then introduced into spaces created by a blunt dissection; one in each side, parallel to the incisions, and the skin was closed with 4.0 silk suture. The distance between the tubes was 16 $\mathrm{mm}$ to avoid interaction between the materials. Each animal received 2 implants of the different materials. Immediately after implantation, the animals were observed until they recovered their physical activities with no feeding restrictions. The animals were seen every day for a maximum period of 60 days.

\section{Histological procedures}

At the end of each experimental period, the animals were anesthetized and killed by administrating high doses of anesthetics. Shaving and incision were performed and the tubes and surrounding tissues were removed with a safety 
margin of $1 \mathrm{~cm}$. The specimens were kept in $10 \%$ formaldehyde solution (Merck \& Co, Darmstadt, Germany) for 2 weeks, until they were histologically processed.

The polyethylene tubes were removed from the specimens, which were then set in prepared paraffin blocks. Sections $5 \mu$ m thick were cut by a microtome and stained with hematoxylin and eosin and three sections from each specimen were selected.

\section{Morphometric analysis}

For histological analysis, 6 histological sections per animal of each cement were included. Each section was analyzed in ten microscopic fields from the region of interest. In total, 60 microscopic fields were evaluated per animal.

The volume density ( $\mathrm{Vvi}$ ) or the fraction of fibrous capsule volume occupied by the fibroblasts, collagen fibers, blood vessels, inflammatory infiltrate (including acute and chronic inflammatory cells) and other structures (spaces occupied by interstitial liquid) was determined by the point volumetric method, using an optical microscope (Aristoplan, Leitz Wetzlar, Germany) with a $100 \times$ objective and $8 \times$ Zeiss $\mathrm{Kpl}$ eyepiece containing a Zeiss II integration grid with 100 points symmetrically distributed over a quadrangular area. For this purpose, the number of points coinciding with each structure $(\mathrm{Pi})$ and the total points analyzed (P) were determined to calculate the percentage of the studied structures and cells.

\section{Statistical analysis}

The data were analyzed using the Kruskal-Wallis test and when statistically significant differences were present among the groups, the Dunn's Multiple Comparison test was utilized. A $p$ value of less than 0.05 was considered statistically significant. Statistical analyses were performed utilizing the SigmaPlot 12 analysis.

\section{RESULTS}

The amount of arsenic $(\mathrm{mg} / \mathrm{kg})$ obtained from each material was: GPC Minetti: $18.46 \mathrm{mg} / \mathrm{kg}$; GPC Votoran: $10.73 \mathrm{mg} / \mathrm{kg}$; GMTA Angelus: $5.91 \mathrm{mg} /$ $\mathrm{kg}$ and WPC Irajazinho: $0.69 \mathrm{mg} / \mathrm{kg}$.

\section{Microscopic analysis}

The analysis of each material includes 360 microscopic areas (60 microscopic fields in 6 animals). At the 15-, 30- and 60-day periods, all specimens displayed a neoformation of connective tissue with a structure of fibrocellular aspect (capsule). Summarized morphometric data of the volume density of collagen fibers, fibroblasts, blood vessels and inflammatory cells are presented in Table 1 and Table 2.

Overall, the lower amount of inflammatory cells was found at the 60-day period, significant differences were found among the materials $(p>0.05)$. The control group showed the lower values of inflammatory cells, followed by MTA Angelus, WPC Irajazinho, Votoran cement and Minetti cement, which showed the higher values of inflammatory cells. Other statistical significances can be found in Table 1.

At 60 days, the experimental groups MTA Angelus, WPC Irajazinho and GPC Votoran showed similar vascular neoformation (Table 2) with exception of GPC Minetti and control group. Regarding the presence of collagen fibers there was an increment of this parameter at the 60-day period in the control group. The number of fibroblasts was constant. The GPC Minetti showed the lower values of collagen fibers in comparison to the other groups. MTA Angelus cement, WPC Irajazinho and GPC Votoran showed similar result. In addition, GPC Minetti showed the higher values of fibroblasts at the initial periods.

\section{Morphologic analysis \\ MTA Angelus}

At 15 days, a thick capsule was juxtaposed to the tubes filled with MTA implanted subcutaneously.

Table 1- Numerical density of inflammatory cells in the capsule adjacent to the empty tubes (control group) and to the tubes filled with cements

\begin{tabular}{cccc}
\hline & 15 Days & 30 Days & 60 Days \\
\hline MTA & $2.0^{\mathrm{b}}(0-15)^{\mathrm{A}}$ & $2.0^{\mathrm{a}}(0-10)^{\mathrm{B}}$ & $1.0^{\mathrm{a}}(0-6)^{\mathrm{C}}$ \\
WPC & $2.0^{\mathrm{b}}(0-16)^{\mathrm{A}}$ & $1.0^{\mathrm{b}}(0-7)^{\mathrm{B}}$ & $2.0^{\mathrm{b}}(0-10)^{\mathrm{A}}$ \\
GPC MINETTI & $4.0^{\mathrm{d}}(0-21)^{\mathrm{A}}$ & $2.0^{\mathrm{d}}(0-15)^{\mathrm{B}}$ & $4.0^{\mathrm{d}}(0-18)^{\mathrm{A}}$ \\
GPC VOTORAN & $6.0^{\mathrm{c}}(0-28)^{\mathrm{A}}$ & $5.0^{\mathrm{c}}(0-20)^{\mathrm{A}}$ & $3.0^{\mathrm{c}}(0-10)^{\mathrm{B}}$ \\
\hline CONTROL & $0^{\mathrm{a}}(0-4.39)^{\mathrm{A}}$ & $0^{\mathrm{e}}(0-1)^{\mathrm{A}}$ & $0^{\mathrm{e}}(0-0)^{\mathrm{B}}$ \\
\hline
\end{tabular}

Same letters represent absence of statistical significance. Uppercase letters represent period. Lowercase letters represent material 
Table 2- Mean of density volume (\%) and standard deviation of histological events shown in connective tissue (capsule) adjacent to the implanted materials and empty tube (control group)

\begin{tabular}{|c|c|c|c|}
\hline \multirow[t]{2}{*}{ Histological events } & \multicolumn{3}{|c|}{ Experimental periods } \\
\hline & 15 days & 30 days & 60 days \\
\hline \multicolumn{4}{|c|}{ MTA Angelus $^{\circledR}$} \\
\hline Fibroblasts & $7.00^{\circ}(1-32)^{A}$ & $5.0^{\mathrm{a}}(1-17)^{\mathrm{B}}$ & $7.0^{c}(1-32)^{c}$ \\
\hline Collagen fibers & $46.0^{\mathrm{C}}(0-87)^{\mathrm{A}}$ & $42.0^{\mathrm{b}}(15-81)^{\mathrm{A}}$ & $35.0^{\mathrm{a}}(16-75)^{\mathrm{B}}$ \\
\hline Blood vessels & $0^{e}(0-16)^{A}$ & $1.0^{d}(0-5)^{B}$ & $0^{\mathrm{a}}(0-16)^{\mathrm{A}}$ \\
\hline \multicolumn{4}{|c|}{ WPC Irajazinho } \\
\hline Fibroblasts & $5.0^{\mathrm{b}}(0-19)^{\mathrm{A}}$ & $6.0^{\mathrm{b}}(0-27)^{\mathrm{B}}$ & $4.0^{\mathrm{a}, \mathrm{b}}(0-14)^{\mathrm{A}}$ \\
\hline Collagen fibers & $46.0^{\mathrm{C}}(13-86)^{\mathrm{A}}$ & $50.5^{\mathrm{a}}(3-79)^{\mathrm{A}}$ & $49.0^{\mathrm{b}}(13-86)^{\mathrm{A}}$ \\
\hline Blood vessels & $0.0^{\mathrm{d}, \mathrm{e}}(0-9)^{\mathrm{A}}$ & $0^{b}(0-5)^{A}$ & $1.0^{\mathrm{b}}(0-6)^{\mathrm{A}}$ \\
\hline \multicolumn{4}{|c|}{ GPC Minetti } \\
\hline Fibroblasts & $13.5^{\mathrm{d}}(0-88)^{\mathrm{A}}$ & $4.0^{\mathrm{a}}(1-17)^{\mathrm{B}}$ & $4.00^{\mathrm{a}}(0-18)^{\mathrm{A}}$ \\
\hline Collagen fibers & $13.0^{\mathrm{a}}(0-86)^{\mathrm{A}}$ & $48.0^{b}(19-68)^{B}$ & $1.0^{d}(0-5)^{c}$ \\
\hline Blood vessels & $0.0^{\mathrm{b}, \mathrm{e}}(0-9)^{\mathrm{A}}$ & $1.0^{\mathrm{c}, \mathrm{d}}(0-11)^{\mathrm{B}}$ & $0^{\mathrm{d}, \mathrm{e}}(0-5)^{\mathrm{c}}$ \\
\hline \multicolumn{4}{|c|}{ GPC Votoran } \\
\hline Fibroblasts & $5.0^{\mathrm{a}, \mathrm{b}}(0-12)^{\mathrm{A}}$ & $5.0^{\mathrm{a}}(0-39)^{\mathrm{A}}$ & $3.0^{\mathrm{b}}(0-12)^{\mathrm{B}}$ \\
\hline Collagen fibers & $44.0^{\mathrm{C}}(20-75)^{\mathrm{A}}$ & $40.5^{\mathrm{a}}(18-83)^{\mathrm{B}}$ & $40^{\mathrm{a}, \mathrm{c}}(20-75)^{\mathrm{c}}$ \\
\hline Blood vessels & $1.0^{\mathrm{C}}(0-19)^{\mathrm{A}}$ & $1.0^{\mathrm{b}, \mathrm{c}}(0-15)^{\mathrm{B}}$ & $1^{c}(0-6)^{A}$ \\
\hline \multicolumn{4}{|c|}{ Control (empty tube) } \\
\hline Fibroblasts & $4.0^{\mathrm{a}}(0-8)^{\mathrm{A}}$ & $4.5^{\mathrm{a}}(2-11)^{\mathrm{A}}$ & $4.0^{\mathrm{a}, \mathrm{b}}(0-7)^{\mathrm{B}}$ \\
\hline Collagen fibers & $27.0^{\mathrm{b}}(3-38)^{\mathrm{A}}$ & $58.0^{\mathrm{C}}(11-76)^{\mathrm{B}}$ & $88.0^{e}(60-97)^{c}$ \\
\hline Blood vessels & $0 a(0-0)^{A}$ & $0^{\mathrm{a}}(0-1)^{\mathrm{A}}$ & $0^{e}(0-5)^{B}$ \\
\hline
\end{tabular}

Same letters represent absence of statistical significance. Uppercase letters represent period. Lowercase letters represent material

Several inflammatory cells were seen mainly in the inner portion of the capsule. After 15 days, multinucleated giant cells were found adjacent to MTA (Figure 1). At 30 days, more organized capsules were found with collagen fibers containing several fibroblasts. Collagen fibers were thicker and blood vessels less numerous and there was fewer empty spaces. A significant reduction of the inflammatory process was verified after 30 and 60 days in comparison to 15 days (Table 1 ). The inflammatory process contained mainly plasma cells and macrophages, which were mainly situated around the blood vessels. Usually, a connective tissue exhibiting well-defined bundles of collagen fibers was present at 60 days. Few interstitial spaces and several elongated fibroblasts were also found at this period (Figure 2).

\section{WPC Irajazinho}

At 15 days, a thick fibrous capsule was observed around the implanted material, besides disorganized collagen fiber network with several formed vessels and fibroblasts (Figure 1 and Table 2). After 15 days of implantation, several inflammatory cells were present in the capsule and macrophages were often observed in close juxtaposition to the material (Figure 1). At 30 days, lymphocytes, macrophages and multinucleated giant cells were present throughout the capsule. At 60 days, the thickness of the fibrous capsule decreased and presented few inflammatory cells (Figure 2 and Table 1 ). Organized collagen fibers and several elongated fibroblasts with an arrangement rather parallel to cement surface constituted the capsule. At 30 days, a reduction in the number of inflammatory cells was verified when compared to 15 days; however, an increase in the amount of inflammatory cells was found at 60 days (Table 1 ).

\section{GPC groups (Minetti and Votoran)}

At 15 days, the capsule was thick with collagen fibers arranged around the cement. A disorganized collagen fiber network with several newly formed vessels and a large number of fibroblasts (Table 2) was present, showing high synthetic activity. A high numerical density of inflammatory cells was verified in the capsule surrounding the implants containing GPC (Table 1). Several mononuclear macrophages 


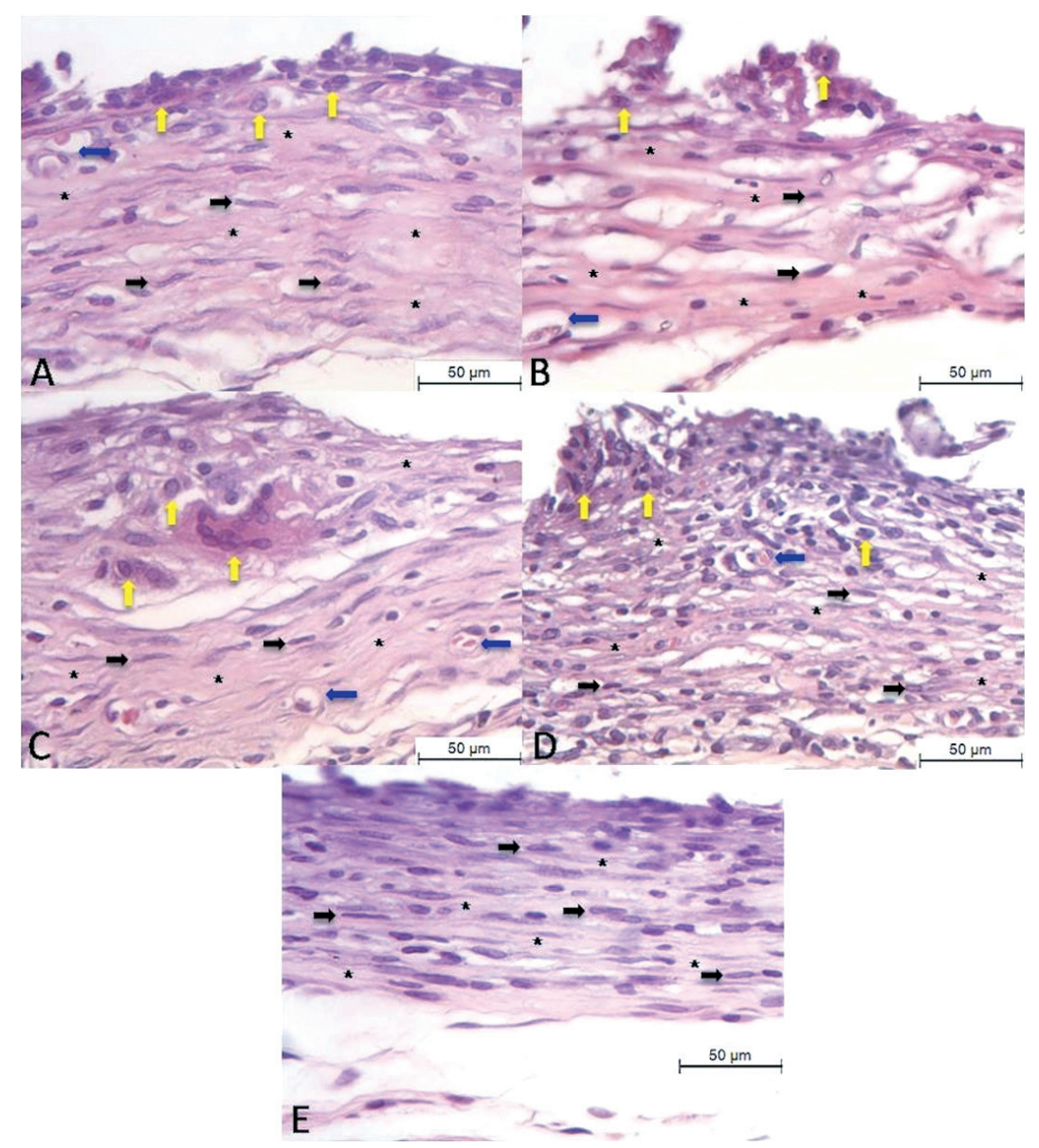

Figure 1- Histological images of inflammatory cells infiltration at the end of implanted tubes at the end of the 15-day period. (A) GMTA. (B) WPC. (C) GPC Minetti. (D) GPC Votoran. (E) Control group. Presence of collagen fibers arranged to the cement (asterisks), fibroblasts (black arrows), blood vessels (blue arrows) and macrophages/multinucleated giant cells (yellow arrows). Hematoxylin and eosin staining, bars represent $50 \mu \mathrm{m}$

and multinucleated giant cells in close juxtaposition to the implanted cement surface were seen in the capsule (Figure 1). Moreover, the inflammatory process contained mainly lymphocytes. At 60 days, the number of inflammatory cells was significantly lower in comparison to 15 days in the Votoran cement (Table 1). The Minetti cement showed an improvement of the inflammatory reaction at the 30 days period but an increase in the inflammatory reaction was observed at the 60 days period $(p>0.05)$. Besides the reduction in the inflammatory reaction in the Votoran cement, several fibroblasts and collagen fibers were present in the capsule. At 60 days, the capsule was formed by a dense connective tissue containing evident bundles of collagen fibers (Figure 2).

\section{Control group (empty tube)}

At 15 days, the capsule adjacent to the empty tubes implanted in the subcutaneous tissue exhibited a mild inflammatory process; evident fibroblasts and blood vessels were present (Table 2 ). The adjacent area of tube surface presented some macrophages and no other type of inflammatory cells (Table 1) was observed (Figure 1). At 30 days the capsule was formed by a typical dense connective tissue, in addition to a significant reduction in the number of inflammatory cells (Table 1 ). At 60 days, the fibrous capsule was well organized with denser collagen fibers, few interstitial spaces, several elongated fibroblasts and absence of inflammatory process (Table 1 and Figure 2).

\section{DISCUSSION}

Endodontic materials are frequently placed in close contact with the periodontium, such as pulp capping, apical barrier, perforation repair, root-end filling material, and orthograde filling material. Thus the materials require the necessary preliminary test, because the toxic components present in these materials could produce irritation or even degeneration of the surrounding tissues.

Implantation of endodontic materials into the subcutaneous connective tissue in rats is considered a valid secondary screening test for biocompatibility ${ }^{27}$. The implantation of materials in polyethylene tubes has been widely accepted. The 


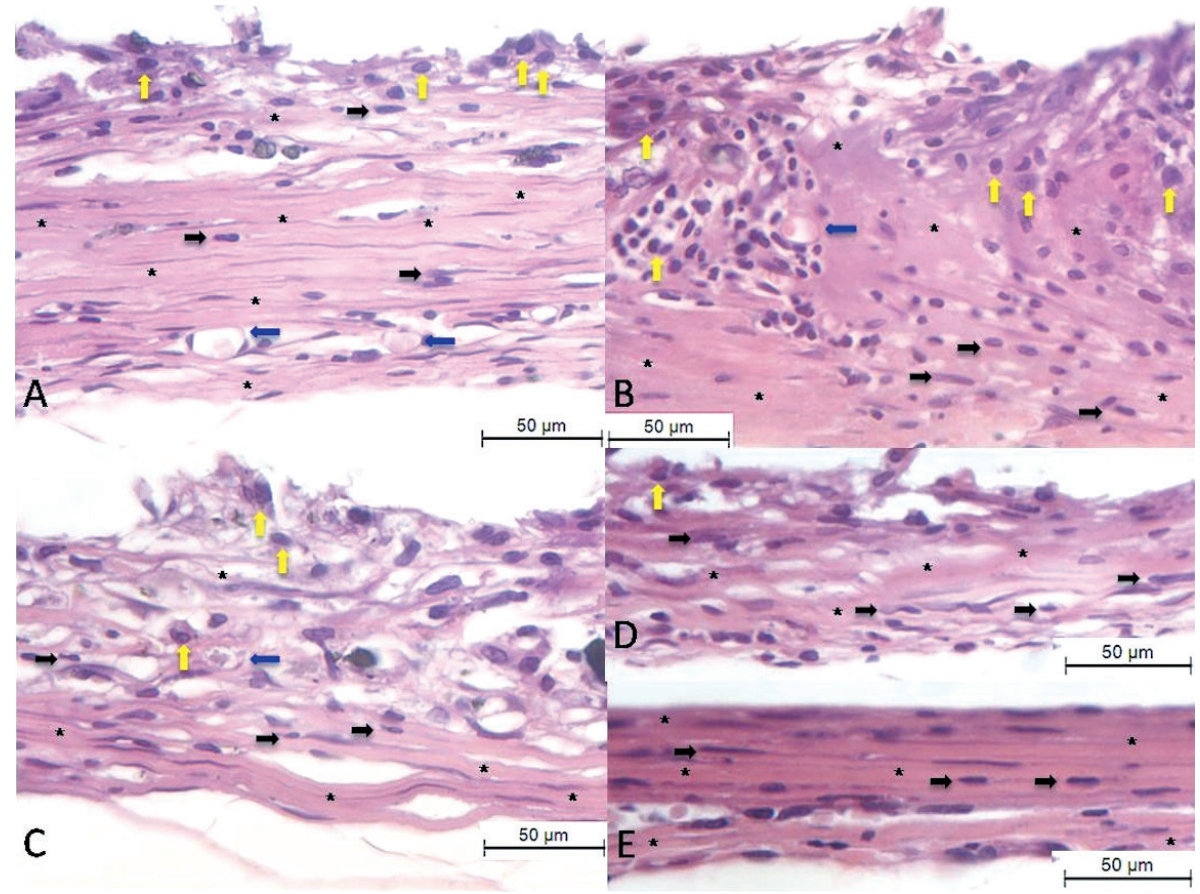

Figure 2- Histological images of inflammatory cells infiltration at the end of implanted tubes at the end of the 60-day period. (A) GMTA. (B) WPC. (C) GPC Minetti. (D) GPC Votoran. (E) Control group. Presence of collagen fibers arranged to the cement (asterisks), fibroblasts (black arrows), blood vessels (blue arrows) and macrophages/multinucleated giant cells (yellow arrows). Hematoxylin and eosin staining, bars represent $50 \mu \mathrm{m}$

tubes help fix the material at the site to maintain proper contact between the material and tissues. In this study, the lateral walls of the polyethylene tubes were used as the control group because the material by itself has been proven to be biocompatible ${ }^{27}$, a finding that was confirmed in the current study.

The presence of arsenic in the Portland cement and the MTA is a problem with regards to biocompatibility ${ }^{14}$. Although a significant amount of arsenic is present in the different types of these materials ${ }^{3,4}$, its release is usually small6,7,15. The ISO 9917-1 standard ${ }^{13}$ specifies the limit of $2 \mathrm{mg} /$ $\mathrm{kg}$ for the total arsenic content in the materials and not for the release. Studies have shown that the levels of arsenic released by MTA Angelus and Portland cement are below what is considered toxic to human health?

The materials analyzed in this study showed, according to atomic absorption spectrophotometry, the following doses of arsenic: GPC Minetti 18.46 $\mathrm{mg} / \mathrm{kg}$, GPC Votoran 10.76 mg/kg, GMTA Angelus $5.01 \mathrm{mg} / \mathrm{kg}$ and WPC Irajazinho $0.69 \mathrm{mg} / \mathrm{kg}$. Overall, all materials in the three experimental periods showed a greater inflammatory response than the control group. The gray Portland cements Minetti and Votoran showed the highest concentration of arsenic in the atomic absorption spectrophotometry (18.46 mg/kg and $10.73 \mathrm{mg} / \mathrm{kg}$, respectively) and were the materials that showed a more pronounced inflammatory response, specially GPC Minetti. However, the little amount of arsenic present in
WPC Irajazinho did not necessarily represent a lower inflammatory reaction.

An interesting finding was observed in the GMTA Angelus group: even with a higher concentration of arsenic ( $5.91 \mathrm{mg} / \mathrm{kg}$ ) according to the ISO standard, it showed statistically lower values of inflammatory response in comparison to WPC Irajazinho $(0.69 \mathrm{mg} / \mathrm{kg})$ in the initial and final periods. The lower inflammatory reaction in GMTA Angelus, compared to the other Portland cements may be related to the presence of some impurities and other heavy metals within these non-dental cements ${ }^{4,6,15,18}$. This depends on where the mineral was extracted ${ }^{4}$, which may affect the proportion of heavy metals in the composition of the cement. Heavy metals are incorporated from the substitution of primary fuels to reduce costs with alternate fuels, which are usually wastes, and also by the utilization of wastes, an alternative inorganic raw material along with limestone and shale ${ }^{19}$. In addition to the arsenic content, Portland cement has been reported to contain more heavy metals, such as manganese and strontium, than MTA, and may induce rejection, inflammation, or allergic reactions ${ }^{5,18}$. Another study ${ }^{19}$ showed that variable amounts of chromium, nickel, and cobalt were contained in some commercial Portland cements ${ }^{4}$.

In clinical endodontic procedures, MTA is used in less than $1 \mathrm{~g}$. Considering that the median lethal dose (LD50) for arsenic trioxide administered orally is 2 to $3 \mathrm{mg}$ per $\mathrm{kg}$ of body weight, the toxic dose 
for an individual weighing $70 \mathrm{~kg}$ would be 140 to $210 \mathrm{mg}$, whereas this amount is considerably higher than the arsenic content present in the Portland cement used for a root end filling. Despite the fact that the cement with the lower amount of arsenic according to the ISO standard (WPC Irajazinho) has not produced lower values of inflammatory cells, cements with higher amounts of arsenic, as 18 $\mathrm{mg} / \mathrm{kg}$, are able to produce a severe inflammatory reaction that showed a statistically lower amount of fibers and higher amount of inflammatory cells.

\section{CONCLUSIONS}

There was no direct relationship between the concentration of arsenic present in the composition of the materials and the intensity of the inflammatory reaction. Higher values as $18.46 \mathrm{mg} /$ $\mathrm{kg}$ of arsenic in the cement produce characteristics of severe inflammatory reaction at the 60-day period. The best results were found in MTA Angelus.

\section{ACKNOWLEDGEMENTS}

The authors deny any conflicts of interest related to this study. The authors thank the Nacional Council for Scientific and Technological Development (CNPq) [Process no. 134982/2009-6] for the financial support.

\section{REFERENCES}

1- Abdullah D, Pitt Ford TR, Papaioannou S, Nicholson J, McDonald F. An evaluation of accelerated Portland cement as a restorative material. Biomaterials. 2002;23:4001-10.

2- Asgary S, Parirokh M, Eghbal MJ, Brink F. Chemical differences between white and gray mineral trioxide aggregate. J Endod. 2005;31:101-3.

3- Bramante CM, Demarchi AC, Moraes IG, Bernardineli N, Garcia RB, Spångberg LS, et al. Presence of arsenic in different types of MTA and white and gray Portland cement. Oral Surg Oral Med Oral Pathol Oral Radiol Endod. 2008;106:909-13.

4- Chang SW, Shon WJ, Lee W, Kum KY, Baek SH, Bae KS. Analysis of heavy metal contents in gray and white MTA and 2 kinds of Portland cement: a preliminary study. Oral Surg Oral Med Oral Pathol Oral Radiol Endod. 2010;109:642-6.

5- Dammaschke T, Gerth HU, Züchner H, Schäfer E. Chemical and physical surface and bulk material characterization of white ProRoot MTA and two Portland cements. Dent Mater. 2005;21:7318

6- De-Deus G, Souza MC, Sergio Fidel RA, Fidel SR, Campos RC, Luna AS. Negligible expression of arsenic in some commercially available brands of Portland cement and mineral trioxide aggregate. J Endod. 2009;35:887-90.

7- Duarte MA, Oliveira Demarchi AC, Yamashita JC, Kuga MC, Campos Fraga S. Arsenic release provided by MTA and Portland cement. Oral Surg Oral Med Oral Pathol Oral Radiol Endod. 2005;99:648-50.
8- Estrela C, Bammann LL, Estrela CR, Silva RS, Pécora JD. Antimicrobial and chemical study of MTA, Portland cement, calcium hydroxide paste, Sealapex and Dycal. Braz Dent J. 2000;11:3-9. 9- Garip H, Salih IM, Sener BC, Göker K, Garip Y. Management of arsenic trioxide necrosis in the maxilla. J Endod. 2004;30:732-6. 10- Holland R, Souza V, Nery MJ, Faraco Júnior IM, Bernabé $\mathrm{PF}$, Otoboni Filho JA, et al. Reaction of rat connective tissue to implanted dentin tube filled with mineral trioxide aggregate, Portland cement or calcium hydroxide. Braz Dent J. 2001;12:3-8. 11- Hughes MF. Arsenic toxicity and potential mechanisms of action. Toxicol Lett. 2002;133:1-16.

12- Hwang YC, Lee SH, Hwang IN, Kang IC, Kim MS, Kim SH, et al. Chemical composition, radiopacity, and biocompatibility of Portland cement with bismuth oxide. Oral Surg Oral Med Oral Pathol Oral Radiol Endod. 2009;107:e96-102.

13- International Standardization Organization. ISO 9917-1: Dentistry - Waterbased cements - Part 1: Powder/liquid acid-base cements. Geneva: ISO; 2003. 22 p.

14- Islam I, Chng HK, Yap AU. Comparison of the physical and mechanical properties of MTA and Portland cement. J Endod. 2006;32:193-7.

15- Matsunaga T, Tsujimoto M, Kawashima T, Tsujimoto $Y$, Fujiwara $M$, Ookubo A, et al. Analysis of arsenic in gray and white mineral trioxide aggregates by using atomic absorption spectrometry. J Endod. 2010;36:1988-90.

16- Rossman TG. Mechanism of arsenic carcinogenesis: an integrated approach. Mutat Res. 2003;533:37-65.

17- Saidon J, He J, Zhu Q, Safavi K, Spångberg LS. Cell and tissue reactions to mineral trioxide aggregate and Portland cement. Oral Surg Oral Med Oral Pathol Oral Radiol Endod. 2003;95:483-9.

18- Schembri M, Peplow G, Camilleri J. Analyses of heavy metals in mineral trioxide aggregate and Portland cement. J Endod. 2010;36:1210-5.

19- Tanomaru-Filho M, Tanomaru JM, Barros DB, Watanabe E, Ito IY. In vitro antimicrobial activity of endodontic sealers, MTA-based cements and Portland cement. J Oral Sci. 2007;49:41-5.

20- Torabinejad M, Ford TR, Abedi HR, Kariyawasam SP, Tang HM. Tissue reaction to implanted root-end filling materials in the tibia and mandible of guinea pigs. J Endod. 1998;24:468-71.

21- Torabinejad M, Hong CU, McDonald F, Pitt Ford TR. Physical and chemical properties of a new root-end filling material. J Endod. 1995;21:349-53.

22- Torabinejad M, Hong CU, Pitt Ford TR, Kettering JD. Antibacterial effects of some root end filling materials. J Endod. 1995;21:403-6.

23- Torabinejad M, Smith PW, Kettering JD, Pitt Ford TR. Comparative investigation of marginal adaptation of mineral trioxide aggregate and other commonly used root-end filling materials. J Endod. 1995;21:295-9.

24- Torabinejad M, Watson TF, Pitt Ford TR. Sealing ability of a mineral trioxide aggregate when used as a root end filling material. J Endod. 1993;19:591-5.

25- Torabinejad M, White DJ; Loma Linda University. Tooth filling material and method of use. US Patent 54155471995 May 16. 26- Yavuz MS, Kaya GS, Yalçin E, Aras MH. Mandibular bone necrosis caused by use of arsenic paste during endodontic treatment: two case reports. Int Endod J. 2008;41:633-7.

27- Zmener O, Martinez Lalis R, Pameijer CH, Chaves C, Kokubu G, Grana D. Reaction of rat subcutaneous connective tissue to a mineral trioxide aggregate-based and a zinc oxide and eugenol sealer. J Endod. 2012;38(9):1233-8. 